\title{
Synthesis of n.c.a. [188, 189, 191pt] Cisplatin From a Cyclotron-produced n.c.a. $188,189,{ }^{191} \mathrm{PtCl}_{4}{ }^{2}$ Complex
}

\section{Honoka Obata}

National Institutes for Quantum and Radiological Science and Technology

\section{Katsuyuki Minegishi}

National Institutes for Quantum and Radiological Science and Technology

Kotaro Nagatsu ( $\square$ nagatsu.kotaro@qst.go.jp )

National Institutes for Quantum and Radiological Science and Technology

\section{Mikako Ogawa}

Hokkaido University

\section{Ming Zhang}

National Institutes for Quantum and Radiological Science and Technology

\section{Research Article}

Keywords: Platinum radionuclide, Auger electron, Cisplatin, Radiotheranostics, Iridium target, Resin extraction, Anion exchange chromatography

Posted Date: December 10th, 2020

DOl: https://doi.org/10.21203/rs.3.rs-123288/v1

License: (a) This work is licensed under a Creative Commons Attribution 4.0 International License. Read Full License

Version of Record: A version of this preprint was published at Scientific Reports on April 14th, 2021. See the published version at https://doi.org/10.1038/s41598-021-87576-2. 


\section{Abstract}

We developed a novel method for production of no-carrier-added (n.c.a.) $\left[{ }^{188,189,191} \mathrm{Pt}^{\mathrm{Pt}} \mathrm{Pt}^{\rrbracket} \mathrm{Cl}_{4}{ }^{2-}\right.$ from an Ir target material, and then synthesized n.c.a. [ $\left.{ }^{*} \mathrm{Pt}\right] \mathrm{cis}-\left[\mathrm{Pt}^{\mathrm{I}} \mathrm{Cl}_{2}\left(\mathrm{NH}_{3}\right)_{2}\right]\left(\left[{ }^{*} \mathrm{Pt}\right] \mathrm{cisplatin}\right)$ from $\left[{ }^{*} \mathrm{Pt}\right] \mathrm{Pt}^{\natural} \mathrm{Cl}_{4}{ }^{2-}$. $\left[{ }^{*} \mathrm{Pt}\right] \mathrm{Pt}^{\natural} \mathrm{Cl}_{4}{ }^{2-}$ was prepared as a synthetic precursor of n.c.a. ${ }^{*} \mathrm{Pt}$ complex by a combination of resin extraction and anion-exchange chromatography after the selective reduction of $\mathrm{Ir}^{\mathrm{D}} \mathrm{Cl}_{6}{ }^{2-}$ with ascorbic acid. The ligand-substitution reaction of $\mathrm{Cl}$ with $\mathrm{NH}_{3}$ was promoted by treating n.c.a. [ $\left.{ }^{*} \mathrm{Pt}\right] \mathrm{Pt}^{\natural} \mathrm{Cl}_{4}{ }^{2-}$ with excess $\mathrm{NH}_{3}$ and heating the reaction mixture, and n.c.a [*Pt]cisplatin was successfully produced without employing precipitation routes. After this treatment, [ ${ }^{\star}$ Pt]cisplatin was isolated through preparative HPLC with a radiochemical purity of $99+\%$ at the end of synthesis (EOS).

\section{Introduction}

Targeted radionuclide therapy (TRT) is a type of radiation therapy in which malignant tissues are internally irradiated with radiopharmaceuticals emitting with $\beta$-ray, $\alpha$-ray, or Auger electron (Auger $e)$ ). $\beta$ rays are the most commonly used in the clinic. Recently, $\alpha$-rays have attracted a great deal of interest because of their high therapeutic efficacy, e.g., ${ }^{225}$ Ac-PSMA-617 for metastatic castration-resistant prostate cancer [1]. Auger $e^{-}$, the third candidate, are also expected to be used in TRT, and many radiopharmaceuticals labeled with Auger $e^{-}$emitters (e.g., ${ }^{123,125}$ I and ${ }^{111} \mathrm{In}$ ) have been developed [2]. However, the therapeutic efficacy has been modest or low in clinical trials performed to date [3-7], and the causes and potential solutions remain unexplored.

An Auger $e^{-}$is a low-energy electron released following inner-shell excitation, and each excited atom emits multiple Auger $e^{-}$. The range of Auger $e^{-}$is extremely short, 2-500 nm, yielding a high linear energy transfer (LET) of 4-26 keV/ $\mu \mathrm{m}$ in the limited nano-scale range [8]. For example, the locally absorbed radiation dose around an ${ }^{125} \mathrm{I}$ decay site was estimated to be $1.6 \mathrm{MGy}$ within a radius of $2 \mathrm{~nm}$ [9]. The effective range of Auger $e^{-}$is smaller than a single cell, suggesting that it is necessary to transport radiopharmaceuticals to intracellular regions that are sensitive to radiation. DNA is expected to be a prime target of Auger $e^{-}$therapy [2,10-13]. More double-strand breaks can be induced when an Auger $e^{-}$ emitter is closer to the DNA [14-16], suggesting that radiopharmaceuticals must be brought as close as possible to DNA to ensure an efficient interaction between Auger $e^{-}$and DNA in the nano-scale range. Therefore, in many radiopharmaceuticals developed to date, Auger-emitting radionuclides of $123,125 \mathrm{I}$ and ${ }^{111}$ In were labeled to DNA-targeting molecules, e.g., a nucleic acid derivative such as deoxyuridine (UdR) $[3,17]$, a nuclear localization signal (NLS) $[12,18]$, or a DNA-binding molecule [19-21], to ensure their transport to DNA. Although antimetabolites based on nucleic acid derivatives are incorporated into DNA, they are limited for use in TRT treatment due to their unavoidable distribution in the intestinal tract, which is radiosensitive. In almost all drugs, however, Auger $e^{-}$emitters labeled to DNA-targeting molecules are either not combined with DNA, or are combined indirectly through an intermediary molecule; consequently, there is expected to be a distance between the DNA and the Auger $e^{-}$emitter. Auger $e^{-}$ 
emitters directly combined with DNA may induce DNA damage most efficiently, but most radioelements are not combined with DNA by themselves. Radioelements should be labeled to intermediary DNAtargeting molecules when being transported to DNA, and such drug design is unalterable.

Platinum has a natural property that is useful in this context. Many platinum complexes (e.g., cisplatin, carboplatin, and oxaliplatin) have been used as platinum-based antineoplastic drugs, and platinum complexes with appropriate leaving groups can form direct DNA adducts between Pt and nucleobases [22]. ${ }^{191} \mathrm{Pt}\left(T_{1 / 2}=2.80 \mathrm{~d}, \mathrm{EC}=100 \%\right),{ }^{193 \mathrm{~m}} \mathrm{Pt}\left(T_{1 / 2}=4.33 \mathrm{~d}, \mathrm{IT}=100 \%\right)$, and ${ }^{195 \mathrm{~m}} \mathrm{Pt}\left(T_{1 / 2}=4.01 \mathrm{~d}, \mathrm{IT}=\right.$ $100 \%$ ), summarized in Table $1[23,24]$, are promising candidate radionuclides [25] that have a suitable half-life and a very high Auger $e^{-}$yield, e.g., an average of 32.8 electrons emitted per decay for ${ }^{195 \mathrm{~m}} \mathrm{Pt}$ vs. 14.7 electrons for ${ }^{111}$ In [26]. Therefore, platinum complexes labeled with radio-Pt as the center metal allow many Auger $e^{-}$to be released very close to DNA, and are therefore appropriate for detailed studies to make sure of the degree of the therapeutic effect by Auger $e$. In this work, we focus on cis- $\left[\mathrm{Pt}^{\natural} \mathrm{Cl}_{2}\left(\mathrm{NH}_{3}\right)_{2}\right]$ (cis-diamminedichloroplatinum (II)), commonly called cisplatin, which can form direct DNA adducts between Pt and nucleobase as an intra-stand cross-link [22]. Cisplatin is a widely used chemotherapeutic agent, and its value is supported by a large number of basic and clinical studies over the years. In the clinic, cisplatin is also used in combination with external radiation because it can increase therapeutic efficacy by causing DNA damage via different routes [27]. Because radio-Pt-labeled cisplatin acts as both an anticancer agent that can target and chemically damage DNA and an Auger $e^{-}$emitter, it is expected to provide a superior therapeutic effect as an in vivo radio-chemotherapy agent.

Contrary to these expectations, however, the production method of no-carrier-added (n.c.a.) radio-Pt remains to be established at a practical level. Although the degree of therapeutic efficacy was reported in previous studies using carrier-added radio-cisplatin with low specific activity ( MBq/mg) [28, 29], it was doubtful whether the fundamental potential of Auger $e^{-}$itself could be detected without being masked by the chemotherapeutic effects of non-radioactive cisplatin carriers. To reveal the therapeutic potential of Auger $e^{-}$, the DNA-damaging effect of radio-cisplatin needs to be investigated using n.c.a. radio-Pt.

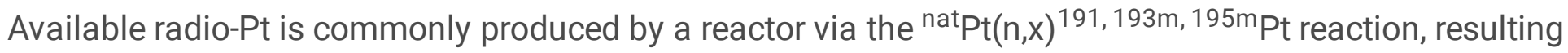
in carrier-added radio-Pt derived from a non-radioactive Pt target material. Although n.c.a. ${ }^{191}{ }^{193 \mathrm{~m} P t}$ can be produced by a cyclotron from a target material of iridium (Ir) or osmium (Os), several issues related to the chemical properties of both Ir and Os make it difficult to produce ${ }^{191,193 \mathrm{~m}} \mathrm{Pt}$ with high yield and high purity [30-33]. Therefore, we demonstrated the production of n.c.a. ${ }^{191} \mathrm{Pt}$ from an Ir target using a cyclotron [34, 35]. In this work, we established a procedure for producing n.c.a. ${ }^{*} \mathrm{Pt}^{\square} \mathrm{Cl}_{4}{ }^{2-}$ as a synthetic precursor of n.c.a. *Pt complex, as well as a method for synthesis of n.c.a. [*Pt]cisplatin from n.c.a. ${ }^{*} \mathrm{Pt}^{\mathrm{D}} \mathrm{Cl}_{4}{ }^{2-}$. In the experiments for this study, we used mixed ${ }^{188,189,191} \mathrm{Pt}\left(81.7 \pm 0.4 \%\right.$ of ${ }^{189} \mathrm{Pt}, 17.6 \pm 0.6 \%$ of ${ }^{191} \mathrm{Pt}$, and $0.7 \pm 0.2 \%$ of ${ }^{188} \mathrm{Pt}$ at the end of bombardment [EOB]), described as * $\mathrm{Pt}$ in the following, because ${ }^{188,189} \mathrm{Pt}$ is co-produced along with ${ }^{191} \mathrm{Pt}$ from a natural Ir target.

\section{Materials And Methods}




\section{General}

Natural Ir powder (99.9\%, $\mathrm{d}_{50}=22.560 \mu \mathrm{m}$ [median size]) was purchased from Furuya Metal (Tokyo, Japan), and sodium peroxide (95区) was purchased from Hayashi Pure Chemical Industry (Osaka, Japan). Ascorbic acid injection (500 mg/2 ml) was purchased from Fuso Pharmaceutical Industry (Osaka, Japan). Other chemicals and reagents were purchased from FUJIFILM Wako Pure Chemical (Osaka, Japan), Tokyo Chemical Industry (Tokyo, Japan), Kanto Chemical (Tokyo, Japan), Otsuka Pharmaceutical Factory (Tokyo, Japan), or Sigma-Aldrich (St. Louis, MO, USA), and were used in experiments without further purification. Milli-Q ultrapure water was used for dilution in all experiments.

HPGe $y$-ray spectrometry was used for radioactivity measurements. The HPGe detector (EGC 15-185-R, Eurisys Measures, Strasbourg, France) was coupled with a 4096 multi-channel analyzer (RZMCA, Laboratory Equipment, Ibaraki, Japan), and calibrated using a mixed $\left({ }^{109} \mathrm{Cd},{ }^{57} \mathrm{Co},{ }^{139} \mathrm{Ce},{ }^{51} \mathrm{Cr},{ }^{85} \mathrm{Sr},{ }^{137} \mathrm{Cs}\right.$, ${ }^{54} \mathrm{Mn},{ }^{88} \mathrm{Y}$, and ${ }^{60} \mathrm{Co}$ ) standard source (Japan Radioisotope Association, Tokyo, Japan). The efficiencies of each chemical separation process were defined as the ratio of ${ }^{191} \mathrm{Pt}$ radioactivity after separation vs. before separation.

The HPLC system (PU-4080i; MD-4010, Jasco, Tokyo, Japan) was equipped with a 200- $\mu$ L (analysis) or 1$\mathrm{mL}$ (preparative isolation) sample loop and a radiation detector (US-3000, Universal Giken, Kanagawa, Japan). The analysis of ${ }^{*} \mathrm{Pt}^{\llbracket} \mathrm{Cl}_{4}{ }^{2-}$ was performed using a Nucleosil SB anionic exchange column (Chemco Plus Scientific, Osaka, Japan) at a flow rate of $1.5 \mathrm{~mL} / \mathrm{min}$, and eluted with perchlorate solution $\left(\mathrm{MeCN} / \mathrm{H}_{2} \mathrm{O}=40 / 60(\mathrm{v} / \mathrm{v})\right.$ containing $0.1 \mathrm{~mol} / \mathrm{L} \mathrm{NaClO}_{4}$ and $\left.0.04 \mathrm{~mol} / \mathrm{L} \mathrm{HClO}_{4}\right)$. The analysis of [*Pt]cisplatin was performed using a polymer-based aqueous size exclusion chromatography (SEC) column (OHpak SB-804 HQ, Shodex, Showa Denko, Tokyo, Japan) at a flow rate of $1.0 \mathrm{~mL} / \mathrm{min}$, eluted with saline solution. Non-radioactive reference samples, $\mathrm{K}_{2} \mathrm{Pt}^{\llbracket} \mathrm{Cl}_{4}$ prepared in $0.1 \mathrm{~mol} / \mathrm{L} \mathrm{HCl}(0.5 \mathrm{mg} / \mathrm{mL})$, and non-radioactive cisplatin in saline solution $(0.5 \mathrm{mg} / \mathrm{mL})$ were also analyzed to identify respective retention times.

\section{Preparation of n.c.a. ${ }^{*} \mathrm{Pt}-\underline{C l}_{\underline{4}}{ }^{2-}$}

The preparation scheme is shown in Fig. 1; the details of this scheme are as follows. As described

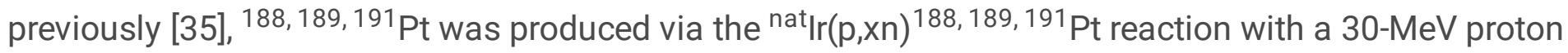
beam for 2-3 h at a beam current of 9-10 $\mathrm{AA}$, and the irradiated Ir target (Ir: $\left.120 \mathrm{mg}, \mathrm{Na}_{2} \mathrm{O}_{2}: 98 \mathrm{mg}\right)$ was dissolved in $6 \mathrm{~mol} / \mathrm{L} \mathrm{HCl}(6 \mathrm{~mL})$. After filtering the solution, a stock solution containing mostly $\operatorname{Ir}^{\square} \mathrm{Cl}_{6}{ }^{2-}$ with trace amounts of ${ }^{*} \mathrm{Pt}^{\square} \mathrm{Cl}_{6}{ }^{2-}$ was prepared. In a typical batch, about $660\left({ }^{189} \mathrm{Pt}\right)+142\left({ }^{191} \mathrm{Pt}\right)+6\left({ }^{188} \mathrm{Pt}\right)$ $\mathrm{MBq}$ of ${ }^{*} \mathrm{Pt}^{\square} \mathrm{Cl}_{6}{ }^{2-}$ was produced at EOB $\left(81.7 \pm 0.4 \%\right.$ of ${ }^{189} \mathrm{Pt}, 17.6 \pm 0.6 \%$ of ${ }^{191} \mathrm{Pt}$, and $0.7 \pm 0.2 \%$ of $\left.{ }^{188} \mathrm{Pt}\right)$ and was used in the experiments.

Ascorbic acid, a reducing agent, was added to the filtered solution to selectively reduce $\operatorname{Ir}^{\square} \mathrm{Cl}_{6}{ }^{2-}($ ascorbic acid injection/Ir solution $=0.15 / 6[\mathrm{v} / \mathrm{v}])$. During this procedure, the dark reddish-brown solution turned 
greenish-yellow, as $\operatorname{Ir}^{\rrbracket} \mathrm{Cl}_{6}{ }^{2-}$ was selectively reduced to $\mathrm{Ir}^{\circledR} \mathrm{Cl}_{6}{ }^{3-}$ whereas ${ }^{*} \mathrm{Pt}^{\natural} \mathrm{Cl}_{6}{ }^{2-}$ remained intact. After the reduction, the mixed solution was loaded into a TBP-resin column made by connecting three TBP-resin cartridges ( $2 \mathrm{~mL}$ cartridge, TrisKem International, Rennes, France), as ${ }^{*} \mathrm{Pt}^{\mathrm{D}} \mathrm{Cl}_{6}{ }^{2-}$ was selectively extracted into the resin. The column was rinsed with $3 \mathrm{~mol} / \mathrm{L} \mathrm{HCl}(5 \mathrm{~mL})$, and then water $(6 \mathrm{~mL})$ was used as an eluting agent. To reduce ${ }^{*} \mathrm{Pt}^{\natural}$ to ${ }^{*} \mathrm{Pt} \mathrm{t}^{\natural}$, an ascorbic acid solution (water + ascorbic acid injection $=2+8 \mathrm{~mL}$ ) was added to the collected elution $(6 \mathrm{~mL})$, yielding a crude ${ }^{*} \mathrm{Pt}^{\natural} \mathrm{Cl}_{4}{ }^{2-}$ solution. The $\mathrm{HCl}$ concentration of this mixed solution was estimated to be $<1 \mathrm{~mol} / \mathrm{L}$.

The resultant crude ${ }^{*} \mathrm{Pt}^{\natural} \mathrm{Cl}_{4}{ }^{2-}$ solution $(16 \mathrm{~mL})$ was loaded onto a column of QMA $(\Phi 15 \times 40 \mathrm{~mm}$, AccellPlus QMA, Waters, Milford, MA, USA) for further purification, and the column was rinsed with 0.01 $\mathrm{mol} / \mathrm{L} \mathrm{HCl}(12 \mathrm{~mL})$. An aqueous solution containing $1.5 \mathrm{~mol} / \mathrm{L} \mathrm{HCl}$ and $0.02 \mathrm{~mol} / \mathrm{L} \mathrm{KCl}$, was used as an eluting agent. The elution was fractionated $(2 \mathrm{~mL}$ each, $\mathrm{f} 1-12)$, and the fractions containing ${ }^{*} \mathrm{Pt}^{\natural} \mathrm{Cl}_{4}{ }^{2-}$ $(\mathrm{f} 5-10)$ were collected based on their radioactivity. The volume of the collected solution was decreased by evaporation, and the ${ }^{*} \mathrm{Pt}^{\complement} \mathrm{Cl}_{4}{ }^{2-}$ product (a precursor of [ ${ }^{*} \mathrm{Pt}$ ]cisplatin) was prepared in $\mathrm{HCl}$ and $\mathrm{KCl}$ solution $(<300 \mu \mathrm{L})$.

\section{Synthesis of n.c.a. $\left[{ }^{*}\right.$ Pt]cisplatin}

The synthesis scheme is shown in Fig. 1. About $900 \mu \mathrm{L}$ of $3 \mathrm{~mol} / \mathrm{L}$ ammonia solution was added to the ${ }^{*} \mathrm{Pt}^{\complement} \mathrm{Cl}_{4}{ }^{2-}$ solution until the $\mathrm{pH}$ reached a value of $8-9$, as determined using a $\mathrm{pH}$ meter (D-72LAB; $9618 \mathrm{~S}$ 10D, HORIBA, Kyoto, Japan). The mixed solution was heated in hot water at $60^{\circ} \mathrm{C}$ for $10 \mathrm{~min}$, and then cooled in ice water. To isolate [ $\left.{ }^{*} \mathrm{Pt}\right]$ cisplatin, preparative HPLC was performed using a polymer-based aqueous size exclusion chromatography (SEC) column (OHpak SB-2004, Shodex, Showa Denko, Tokyo, Japan) at a flow rate of $3.0 \mathrm{ml} / \mathrm{min}$, eluted with physiological saline solution.

\section{Results And Discussion}

\section{Preparation of n.c.a. ${ }^{*} \mathrm{Pt} \underline{\mathrm{Cl}_{4}^{2-}}$}

We prepared n.c.a. ${ }^{*} \mathrm{Pt}^{\square} \mathrm{Cl}_{4}{ }^{2-}$ by a combination of resin extraction and anion exchange chromatography as a precursor for the synthesis of n.c.a. [*Pt]cisplatin. First, ${ }^{*} \mathrm{Pt}^{\natural} \mathrm{Cl}_{6}{ }^{2-}$ was separated from a bulk Ir target through a TBP-resin column extraction after selectively reducing $\operatorname{~Ir}^{\mathrm{C}} \mathrm{Cl}_{6}{ }^{2-}$. Our comprehensive survey of reductants revealed that ascorbic acid had the highest selectivity for the reduction of $\operatorname{Ir}^{\square} \mathrm{Cl}_{6}{ }^{2-}$ in $6 \mathrm{~mol} / \mathrm{L}$ $\mathrm{HCl}$. By contrast, ${ }^{*} \mathrm{Pt}^{\natural} \mathrm{Cl}_{6}{ }^{2-}$ was not reduced at all in $6 \mathrm{~mol} / \mathrm{L} \mathrm{HCl}$, but was easily reduced in dil. $\mathrm{HCl}(<1$ $\mathrm{mol} / \mathrm{L}$ ). As a result of the successful selective reduction of $\mathrm{Ir}^{\square} \mathrm{Cl}_{6}{ }^{2-}$, only ${ }^{*} \mathrm{Pt}^{\square} \mathrm{Cl}_{6}{ }^{2-}$ was extracted from the bulk $\operatorname{Ir}^{\mathrm{D}} \mathrm{Cl}_{6}{ }^{3-}$ solution onto the extraction column. Ascorbic acid enables the selective reduction of $\operatorname{Ir}^{\mathrm{D}} \mathrm{Cl}_{6}{ }^{2-}$ and makes the following separation processes much efficient, compared to acetaldoxime used in our previous study. 
In this work, the solid-phase extraction was applied in place of the liquid-liquid extraction because column separation is more suitable for expansion into a remote automatic device for further development. ${ }^{*} \mathrm{Pt}^{\square} \mathrm{Cl}_{6}{ }^{2-}$ was extracted onto the TBP-resin column in the presence of $\mathrm{HCl}$, and then quickly eluted with $\mathrm{H}_{2} \mathrm{O}$. The extraction efficiencies for the recovery of *Pt were above $90 \%(n=3$, Table 2$)$.

While only $\operatorname{~r}^{\square} \mathrm{Cl}_{6}{ }^{2-}$ was reduced by ascorbic acid in $6 \mathrm{~mol} / \mathrm{L} \mathrm{HCl}$, we found that ascorbic acid is also applicable to reduce ${ }^{*} \mathrm{Pt}^{\natural} \mathrm{Cl}_{6}{ }^{2-}$ to ${ }^{*} \mathrm{Pt}^{\square} \mathrm{Cl}_{4}{ }^{2-}$ in dil. $\mathrm{HCl}$ ( $<1 \mathrm{~mol} / \mathrm{L}$ ). After elution from the TBP-resin column, ${ }^{*} \mathrm{Pt}^{\square} \mathrm{Cl}_{6}{ }^{2-}$ was reduced by ascorbic acid rapidly in $<1 \mathrm{~mol} / \mathrm{L} \mathrm{HCl}$. Then, the crude ${ }^{*} \mathrm{Pt}^{\square} \mathrm{Cl}_{4}{ }^{2-}$ solution was purified by anion exchange chromatography (AEC) with a QMA column. The radiochromatogram obtained during QMA-AEC is shown in Fig. 2. Although $* \mathrm{Pt}^{\natural} \mathrm{Cl}_{4}{ }^{2-}$ was predominantly observed (f2-12), some ${ }^{*} \mathrm{Pt}^{\square} \mathrm{Cl}_{4}{ }^{2-}$ changed to other complexes, which passed through the column without any interaction (f0) or were strongly retained and remained on the column (C), as shown in Fig. 2. Additionally, the early eluted fractions ( $f 1-4)$ were removed from the product because they contained impurities derived from ascorbic acid. As a result of these losses, a pure fraction of n.c.a. ${ }^{*} \mathrm{Pt}^{\square} \mathrm{Cl}_{4}{ }^{2-}$ was isolated at an efficiency of $60-70 \%\left(n=3\right.$, Table2). Overall, as summarized in Table 2, the efficiency of the preparation of ${ }^{*} \mathrm{Pt}^{\natural} \mathrm{Cl}_{4}{ }^{2-}$ was nearly constant, and the n.c.a. ${ }^{*} \mathrm{Pt}^{\rrbracket} \mathrm{Cl}_{4}{ }^{2-}$ product was obtained. Furthermore, no organic solvents were used in our method for separation of ${ }^{*} \mathrm{Pt}^{\complement} \mathrm{Cl}_{6}{ }^{2-}$ from a bulk Ir target, which contributes the green chemistry and reduces the workloads on the quality control.

\section{Synthesis of n.c.a. [*Pt]cisplatin}

Bulk cisplatin is commonly produced by forming a crystal precipitate [36], but this approach is difficult to apply to n.c.a. radionuclides. Therefore, we synthesized n.c.a. [ $\left.{ }^{*} \mathrm{Pt}\right]$ cisplatin from ${ }^{*} \mathrm{Pt}^{\mathrm{D}} \mathrm{Cl}_{4}{ }^{2-}$ in solution, and then separated it by preparative HPLC. The radiochromatogram obtained during preparative isolation is shown in Fig. 3. [ $\left.{ }^{*} \mathrm{Pt}\right]$ cisplatin was detected at a retention time of $28-30 \mathrm{~min}$, in good agreement with the value for non-radioactive cisplatin. The radiochemical yield for [ $\left.{ }^{\star} \mathrm{Pt}\right]$ cisplatin, defined as the ratio of ${ }^{191} \mathrm{Pt}$ radioactivity of isolated [ ${ }^{191} \mathrm{Pt}$ ]cisplatin to the total ${ }^{191} \mathrm{Pt}$ collected after evaporation, was $5-15 \%$. The low efficiency was due to a decrease in ${ }^{*} \mathrm{Pt}^{\natural} \mathrm{Cl}_{4}{ }^{2-}$ purity during evaporation, in addition to the low synthetic yield of the ligand-substitution reaction between $\mathrm{Cl}$ and $\mathrm{NH}_{3}$. In HPLC analyses using an anion-exchange column, the peak intensity of ${ }^{*} \mathrm{Pt}^{\complement} \mathrm{Cl}_{4}{ }^{2-}$ decreased with time, whereas an unknown peak that was not retained on the column and a peak of ${ }^{*} \mathrm{Pt}^{\square} \mathrm{Cl}_{6}{ }^{2-}$ appeared. The purity of ${ }^{*} \mathrm{Pt}^{\square} \mathrm{Cl}_{4}{ }^{2-}$ in the evaporated solution was $60 \%$ or less, suggesting that n.c.a. ${ }^{*} \mathrm{Pt}^{\complement} \mathrm{Cl}_{4}{ }^{2-}$ is unstable. In support of this observation, the synthesis yield was increased to $30-40 \%$ when the collected elution $(1 \mathrm{~mol} / \mathrm{L} \mathrm{HCl}$ and $0.5 \mathrm{~mol} / \mathrm{L} \mathrm{KCl}$ ) from the QMA column was used immediately without evaporation.

Even when the purity of ${ }^{*} \mathrm{Pt}^{\complement} \mathrm{Cl}_{4}{ }^{2-}$ was not so reduced, the synthetic yield was less than $50 \%$. In the conventional synthetic method for bulk cisplatin, the synthetic yield is around $60 \%$ when $\mathrm{K}_{2}\left[\mathrm{Pt}^{\rrbracket} \mathrm{C} 1_{4}\right]$ is treated directly with $\mathrm{NH}_{3}$, and an accurate two equivalents of $\mathrm{NH}_{3}$ to $\mathrm{Pt}$ should be added in order to 
prevent excess ligand substitutions [36, 37]. In this study, we used n.c.a. ${ }^{*} \mathrm{Pt}^{\natural} \mathrm{Cl}_{4}{ }^{2-}$ and treated it with excess $\mathrm{NH}_{3}$, probably resulting in low synthetic yield. Nevertheless, it should be noted that heating was essential to promote the ligand substitution reaction between n.c.a. ${ }^{*} \mathrm{Pt}^{\rrbracket} \mathrm{Cl}_{4}{ }^{2-}$ and excess $\mathrm{NH}_{3}$. Without heating, about $50 \%$ of ${ }^{*} \mathrm{Pt}^{\square} \mathrm{Cl}_{4}{ }^{2-}$ remained unreacted under a $\mathrm{pH}$ value of 9 , indicating that both $\mathrm{NH}_{3}$ and heat to some degree promoted ligand substitution for $\sim 10^{-11} \mathrm{~mol}$ of $* \mathrm{Pt}$, which was interesting from the standpoint of radiochemistry. Although it is quite difficult to finely control the stoichiometric balance of $\mathrm{NH}_{3}$ and n.c.a. ${ }^{*} \mathrm{Pt}^{\natural} \mathrm{Cl}_{4}{ }^{2-}$, an appropriate $\mathrm{NH}_{3}$ concentration may improve the synthesis yield.

Overall, using our method, n.c.a. [ $\left.{ }^{*} \mathrm{Pt}\right]$ cisplatin was finally obtained in saline solution $(6 \mathrm{~mL})$ from ${ }^{*} \mathrm{Pt}^{\mathrm{I}} \mathrm{Cl}_{6}{ }^{2-}$ in a bulk Ir target, and at the end of synthesis (EOS), following a one-day cool-down period after EOB, about $1.29\left({ }^{189} \mathrm{Pt}\right)+1.00\left({ }^{191} \mathrm{Pt}\right)+0.05\left({ }^{188} \mathrm{Pt}\right) \mathrm{MBq} / \mathrm{mL}$ of $\left[{ }^{*} \mathrm{Pt}\right]$ cisplatin was available for further biological studies.

\section{Quality control}

We investigated the radiochemical purity and stability of [*Pt]cisplatin by HPLC analyses. As shown in Fig. 4 (a1), a single peak of [ ${ }^{*} \mathrm{Pt}$ ]cisplatin was observed with a retention time of $14-15 \mathrm{~min}$. The radiochemical purity of n.c.a. [*Pt]cisplatin was $99+\%$ in the final product. Any impurities were below the detection limit in the chromatogram generated by detecting UV absorption at $250 \mathrm{~nm}$. In the sample with low radioactive concentration shown in Fig. $4(\mathrm{a} 1,2)\left(0.37\left({ }^{189} \mathrm{Pt}\right)+0.31\left({ }^{191} \mathrm{Pt}\right)+0.01\left({ }^{188} \mathrm{Pt}\right) \mathrm{MBq} / \mathrm{mL}\right.$ at EOS), [*Pt]cisplatin exhibited good stability in the solution, and radiochemical purity was constant up to $15 \mathrm{~h}$ after EOS. By contrast, in the high radioactive concentration shown in Fig. $4(\mathrm{~b} 1,2)\left(1.76\left({ }^{189} \mathrm{Pt}\right)+\right.$ $1.40\left({ }^{191} \mathrm{Pt}\right)+0.05\left({ }^{188} \mathrm{Pt}\right) \mathrm{MBq} / \mathrm{mL}$ at EOS $)$, [ $\left.{ }^{\star} \mathrm{Pt}\right]$ cisplatin decomposed as time passed. In this higher concentration, the radiochemical purity decreased to $84 \%(6 \mathrm{~h})$ and $54 \%(24 \mathrm{~h})$ after EOS. We assume that $\left[{ }^{*} \mathrm{Pt}\right]$ cisplatin decomposed due to the radiolysis by $\gamma$-ray, X-ray, and Auger $e^{-}$emitted from *Pt.

In HPGe $y$-ray spectrometry, only ${ }^{188,189,191} \mathrm{Pt}$ were detected, and other coexistent radionuclides in a stock solution (e.g., ${ }^{190 g}, 192 \mathrm{~g} / \mathrm{r}$ ) were below the detection limit after purification with QMA-AEC. Due to the overlapping nuclear reaction channels, the product included not only ${ }^{191} \mathrm{Pt}$ but also ${ }^{188,189} \mathrm{Pt}$ [34].

\section{Conclusions}

We developed a novel method for production of ${ }^{*} \mathrm{Pt}^{\rrbracket} \mathrm{Cl}_{4}{ }^{2-}$ from an Ir target by employing the selective reduction of $\mathrm{Ir}^{\square} \mathrm{Cl}_{6}{ }^{2-}$ with ascorbic acid. Using a combination of resin extraction and AEC, we prepared n.c.a. ${ }^{*} \mathrm{Pt}^{\rrbracket} \mathrm{Cl}_{4}{ }^{2-}$ as a precursor of $\left[{ }^{*} \mathrm{Pt}\right]$ cisplatin. N.c.a. $\left[{ }^{*} \mathrm{Pt}\right]$ cisplatin was successfully obtained by treating n.c.a. ${ }^{*} \mathrm{Pt}^{\complement} \mathrm{Cl}_{4}{ }^{2-}$ with excess $\mathrm{NH}_{3}$ and heating the reaction mixture. N.c.a. [ ${ }^{*} \mathrm{Pt}$ ]cisplatin was prepared at high radiochemical purities $(99+\%)$, which is useful for evaluating the biological effects of Auger $e^{-}$using $\left[{ }^{*}\right.$ Pt]cisplatin. 


\section{Declarations}

\section{Acknowledgments}

The authors thank the cyclotron staff for the operation of the NIRS cyclotron AVF-930. We are grateful to Mr. Hisashi Suzuki for technical support and to Dr. Steffen Happel for the sample supply of TBP-resin. This work was supported by JSPS KAKENHI Grant Number JP20J20518.

\section{Author contributions}

H.O and K.M collected data. H.O., K.N., M.O, and M.R.C. designed experiments. H.O., K.N., and M.R.C. wrote the manuscript.

\section{References}

1. Kratochwil C, Bruchertseifer F, Giesel FL, Weis M, Verburg FA, Mottaghy F, Kopka K, Apostolidis C, Haberkorn U, Morgenstern A. ${ }^{225}$ Ac-PSMA-617 for PSMA-targeted a-radiation therapy of metastatic castration-resistant prostate cancer. J Nucl Med 2016; 57:1941-1944.

2. Cornelissen B, Vallis KA. Targeting the nucleus: an overview of auger-electron radionuclide therapy. Curr Drug Discov Technol 2010;7(4):263-279.

3. Rebischung C, Hoffmann D, Stéfani L, Desruet MD, Wang K, Adelstein SJ, Artignan X, Vincent F, Gauchez AS, Zhang H, Fagret D, Vuillez J, Kassis Al, Balosso J. First human treatment of resistant neoplastic meningitis by intrathecal administration of MTX Plus ${ }^{125} / \mathrm{nt} \mathrm{J}$ Radiat Biol 2008;84(12):1123-1129.

4. Vallis KA, Reilly RM, Scollard D, Merante P, Brade A, Velauthapillai S, Caldwell C, Chan I, Freeman M, Lockwood G, Miller NA, Cornelissen B, Petronis J, Sabate K. Phase I trial to evaluate the tumor and normal tissue uptake, radiation dosimetry and safety of ${ }^{111}$ In-DTPA-human epidermal growth factor in patients with metastatic EGFR-positive breast cancer. Am J Nucl Med Mol Imaging 2014;4(2):181192.

5. Jong M, Valkema R, Jamar F, Kvols LK, Kwekkeboom DJ, Breeman WAP, Bakker WH, Smith C, Pauwels S, Krenning EP. Somatostatin receptor-targeted radionuclide therapy of tumors: preclinical and clinical findings. Semin Nucl Med 2002;32(2):133-140.

6. Delpassand ES, Samarghandi A, Mourtada JS, Zamanian S, Espenan GD, Sharif R, MacKenzie S, Kosari K, Barakat O, Naqvi S, Seng JE, Anthony L. Long-term survival, toxicity profile, and role of F-18 FDG PET/CT scan in patients with progressive neuroendocrine tumors following peptide receptor radionuclide therapy with high activity In-111 pentetreotide. Theranostics 2012;2(5):472-480.

7. Welt S, Scott AM, Divgi CR, Kemeny NE, Finn RD, Daghighian F, Germain JS, Richards EC, Larson SM, Old LJ. Phase I/II study of iodine 125-labeled monoclonal antibody A33 in patients with advanced colon cancer. J Clin Oncol 1996;14:1787-1797. 
8. Kassis Al, Adelstein SJ. Radiobiologic principles in radionuclide therapy. J Nucl Med 2005;46:4S$12 \mathrm{~S}$.

9. Kassis Al, Fayad F, Kinsey BM, Sastry KS, Taube RA, Adelstein SJ. Radiotoxicity of ${ }^{125}$ I in mammalian cells. Radiat Res 1987;111:305-318.

10. Martina RF, Feinendegend LE. The quest to exploit the Auger effect in cancer radiotherapy - a reflective review. Int J Radiat Biol 2016;92(11):617-632.

11. Buchegger F, Adamer FP, Dupertuis YM, Delaloye AB. Auger radiation targeted into DNA: a therapy perspective. Eur J Nucl Med Mol Imaging 2006;33:1352-1363.

12. Rosenkranz AA, Slastnikova TA, Georgiev GP, Zalutsky MR, Sobolev AS. Delivery systems exploiting natural cell transport processes of macromolecules for intracellular targeting of Auger electron emitters. Nucl Med Biol 2020;80:45-56.

13. Imstepf $S$, Pierroz V, Raposinho P, Bauwens M, Felber M, Fox T, Shapiro AB, Freudenberg R, Fernandes C, Gama S, Gasser G, Motthagy F, Santos IR, Alberto R. Nuclear targeting with an auger electron emitter potentiates the action of a widely used antineoplastic drug. Bioconjugate Chem 2015;26:2397-2407.

14. Balagurumoorthy $P, X u X$, Wang $K$, Adelstein SJ, Kassis Al. Effect of distance between decaying ${ }^{125}$ I and DNA on Auger-electron induced double-strand break yield. Int J Radiat Bio/ 2012;88(12):9981008.

15. Pereira E, Quental L, Palma E, Oliveira MC, Mendes F, Raposinho P, Correia I, Lavrado J, Maria SD, Belchior A, Vaz P, Santos I, Paulo A. Evaluation of acridine orange derivatives as DNA-targeted radiopharmaceuticals for auger therapy: influence of the radionuclide and distance to DNA. Sci Rep 2017;7:42544.

16. Reissig F, Mamat C, Steinbach J, Pietzsch HJ, Freudenberg R, Retamal CN, Caballero J, Kotzerke J, Wunderlich G. Direct and auger electron-induced, single and double-strand breaks on plasmid DNA caused by ${ }^{99 \mathrm{~m} T c-l a b e l e d}$ pyrene derivatives and the effect of bonding distance. PLOS ONE 2016;11(9):e0161973.

17. Kassis Al, Tumeh SS, Wen PYC, Kortylewicz JB, Abbeele ADV, Zimmerman RE, Carvalho PA, Garada BM, DeSisto WC, Bailey NO, Castronovo FP, Mariani G, Black PM, Adelstein SJ. Intratumoral administration of $\left.5-\left[{ }^{123}\right]\right]$ iodo-2' deoxyuridine in a patient with a brain tumor. J NuCl Med 1966;37:19S-22S.

18. Rosenkranz AA, Slastnikova TA, Karmakova TA, Vorontsova MS, Morozova NB, Petriev VM, Abrosimov AS, Khramtsov YV, Lupanova TN, Ulasov AV, Yakubovskaya RI, Georgiev GP, Sobolev AS. Antitumor activity of auger electron emitter ${ }^{111}$ In delivered by modular nanotransporter for treatment of bladder cancer with EGFR overexpression. Front Pharmacol 2018;9:1331.

19. Yasui LS, Chen K, Wang K, Jones TP, Caldwell J, Gusea D, Kassis Al. Using hoechst 33342 to target radioactivity to the cell nucleus. Radiat Res 2007;167:167-175. 
20. Sato N, Kobayashi H, Saga T, Nakamoto Y, Ishimori T, Togashi K, Fujibayashi Y, Konishi J, Brechbiel $\mathrm{MW}$. Tumor targeting and imaging of intraperitoneal tumors by use of antisense oligo-DNA complexed with dendrimers and/or avidin in mice. Clin Cancer Res 2001;7:3606-3612.

21. Dahmen V, Pomplun E, Kriehuber R. lodine-125-labeled DNA-Triplex-forming oligonucleotides reveal increased cyto- and genotoxic effectiveness compared to Phosphorus-32. Int J Radiat Biol 2016;92(11):679-685.

22. Johnstone TC, Suntharalingam K, Lippard SJ. The next generation of platinum drugs: targeted Pt(II) agents, nanoparticle delivery, and Pt(IV) prodrugs. Chem Rev 2016;116(5):3436-3486.

23. NuDat 2.8, available online at (http://www.nndc.bnl.gov/nudat2/index.jsp).

24. Radionuclide Decay Data, available online at (https://hps.org/publicinformation/radardecaydata.cfm).

25. Qaim SM. Nuclear data for production and medical application of radionuclides: Present status and future needs. Nucl Med Biol 2017;44:31-49.

26. Howell RW. Radiation spectra for Auger-electron emitting radionuclides: Report No.2 of AAPM Nuclear Medicine Task Group No.6. Med Phys 1992;19(6):1371-1383.

27. Sarraf MA, Pajak TF, Marcial VA, Mowry P, Cooper JS, Stetz J, Ensley JF, Garcia EV. Concurrent radiotherapy and chemotherapy with cisplatin in inoperable squamous cell carcinoma of the head and neck. An RTOG Study. Cancer 1987;59(2):259-265

28. Areberg J, Wennerberg J, Johnsson A, Norrgren K, Mattsson S. Antitumor effect of radioactive cisplatin ( $\left.{ }^{191} \mathrm{Pt}\right)$ on nude mice. Int. J. Radiation Oncol. Biol Phys 2001;49(3):827-

29. Norrgren K, Sjölin M, Björkman S, Areberg J, Johnsson A, Johansson L, Mattsson S. Comparative renal, hepatic, and bone marrow toxicity of cisplatin and radioactive cisplatin $\left({ }^{191} \mathrm{Pt}\right)$ in wistar rats. Cancer Biother Radiopharm 2006;21(5):528-534.

30. Parent M, Strijckmans K, Cornelis R, Dewaele J, Dams R. Production of ${ }^{191} \mathrm{Pt}$ radiotracer with high specific activity for the development of preconcentration procedures. Nucl Instrum Methods Phys Res Sect B 1994;86:355-366.

31. Tinker ND, Zweit J, Sharma HL, Downey S, McAuliffe CA. Production of no-carrier added ${ }^{191} \mathrm{Pt}$, a radiolabel for the synthesis and biological investigations of platinum anti-tumour compounds. Acta. 1991;54:29-34.

32. Uddin MS, Scholten B, Hermanne A, Sudár S, Coenen HH, Qaim SM. Radiochemical determination of cross sections of a-particle induced reactions on ${ }^{192} \mathrm{Os}$ for the production of the therapeutic radionuclide ${ }^{193 \mathrm{~m}}$ Appl. Radiat. Isot. 2010;68:2001-2006.

33. Uddin MS, Hermanne A, Scholten B, Spellerberg S, Coenen HH, Qaim SM. Small scale production of high purity ${ }^{193 m} \mathrm{Pt}$ by the ${ }^{192} \mathrm{Os}(\mathrm{a}, 3 \mathrm{n}$ )-process. Radiochim Acta 2011;99:131-135.

34. Obata H, Khandaker MU, Furuta E, Nagatsu K, Zhang MR. Excitation functions of proton- and deuteron-induced nuclear reactions on natural iridium for the production of ${ }^{191} \mathrm{App} /$ Radiat. Isot 2018;137:250-260. 
35. Obata H, Minegishi K, Nagatsu K, Zhang MR, Shinohara A. Production of ${ }^{191} \mathrm{Pt}$ from an iridium target by vertical beam irradiation and simultaneous alkali fusion. Appl Radiat Isot 2019;149:31-

36. Kleinberg J. Inorganic Syntheses, Volume 7. New York: John Wiely \& Sons; 1963. 239 p.

37. Darensbourg MY. Inorganic. Syntheses, Volume 32. New York: John Wiely \& Sons; 1998. 141-144 p.

\section{Tables}

Table 1. Decay characteristics of relevant platinum radionuclides

\begin{tabular}{|llllll|}
\hline & ${ }^{195 \mathrm{~m} P t}$ & ${ }^{193 \mathrm{~m} P t}$ & ${ }^{191} \mathrm{Pt}$ & ${ }^{189} \mathrm{Pt}$ & ${ }^{188} \mathrm{Pt}$ \\
\hline Half-life & $4.01 \mathrm{~d}$ & $4.33 \mathrm{~d}$ & $2.83 \mathrm{~d}$ & $10.87 \mathrm{~h}$ & $10.2 \mathrm{~d}$ \\
\hline Decay scheme & $\mathrm{IT:} 100 \%$ & $\mathrm{IT:} 100 \%$ & EC: $100 \%$ & EC: $100 \%$ & EC: $99+\%$ \\
\hline$\gamma$ & $98.9 \mathrm{keV}$ & $135.5 \mathrm{keV}$ & $538.9 \mathrm{keV}$ & $721.4 \mathrm{keV}$ & $187.6 \mathrm{keV}$ \\
& $(11.7 \%)$ & $(0.11 \%)$ & $(13.7 \%)$ & $(7.9 \%)$ & $(19.1 \%)$ \\
\hline Auger $e^{-}$ & L: $140 \%$ & L: $55.2 \%$ & L: $106 \%$ & L: $108 \%$ & L: $82 \%$ \\
& K: $3.3 \%$ & K: $0.64 \%$ & K: $5.3 \%$ & K: $5.4 \%$ & K: $3.6 \%$ \\
\hline
\end{tabular}

Data for ${ }^{188,189,193 m, 195 \mathrm{~m} P t}$ were taken from NuDat 2.8 [23], and data for ${ }^{191} \mathrm{Pt}$ were taken from Radionuclide Decay Data [24].

Table 2. Chemical separation efficiency of $* \mathrm{Pt}(n=3)$

\begin{tabular}{|lll|}
\hline \multicolumn{3}{|l|}{ Separation of *Pt from an Ir target } \\
\cline { 2 - 3 } & Resin extraction & Purification (AEC) \\
\hline 1 & $91 \%$ & $61 \%$ \\
2 & $93 \%$ & $60 \%$ \\
\hline 3 & $90 \%$ & $70 \%$ \\
\hline
\end{tabular}

Efficiency contains an uncertainty of $5 \%$ in the radioactivity measurement. 
Figures

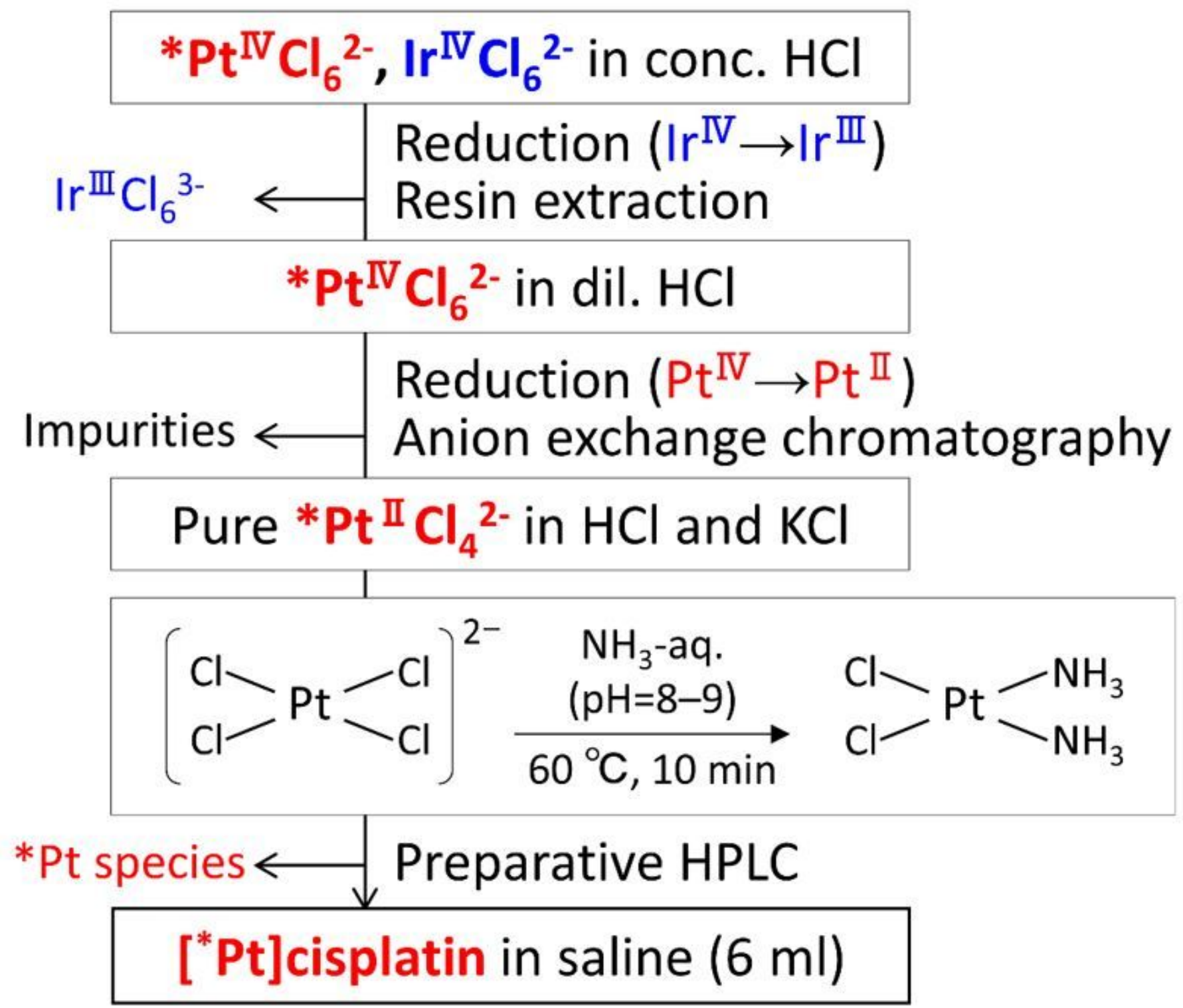

Figure 1

Scheme for preparation of ${ }^{*} \mathrm{Pt} \rrbracket \mathrm{Cl} 42$ - and synthesis of $\left[{ }^{*} \mathrm{Pt}\right] \mathrm{cisplatin}$ 


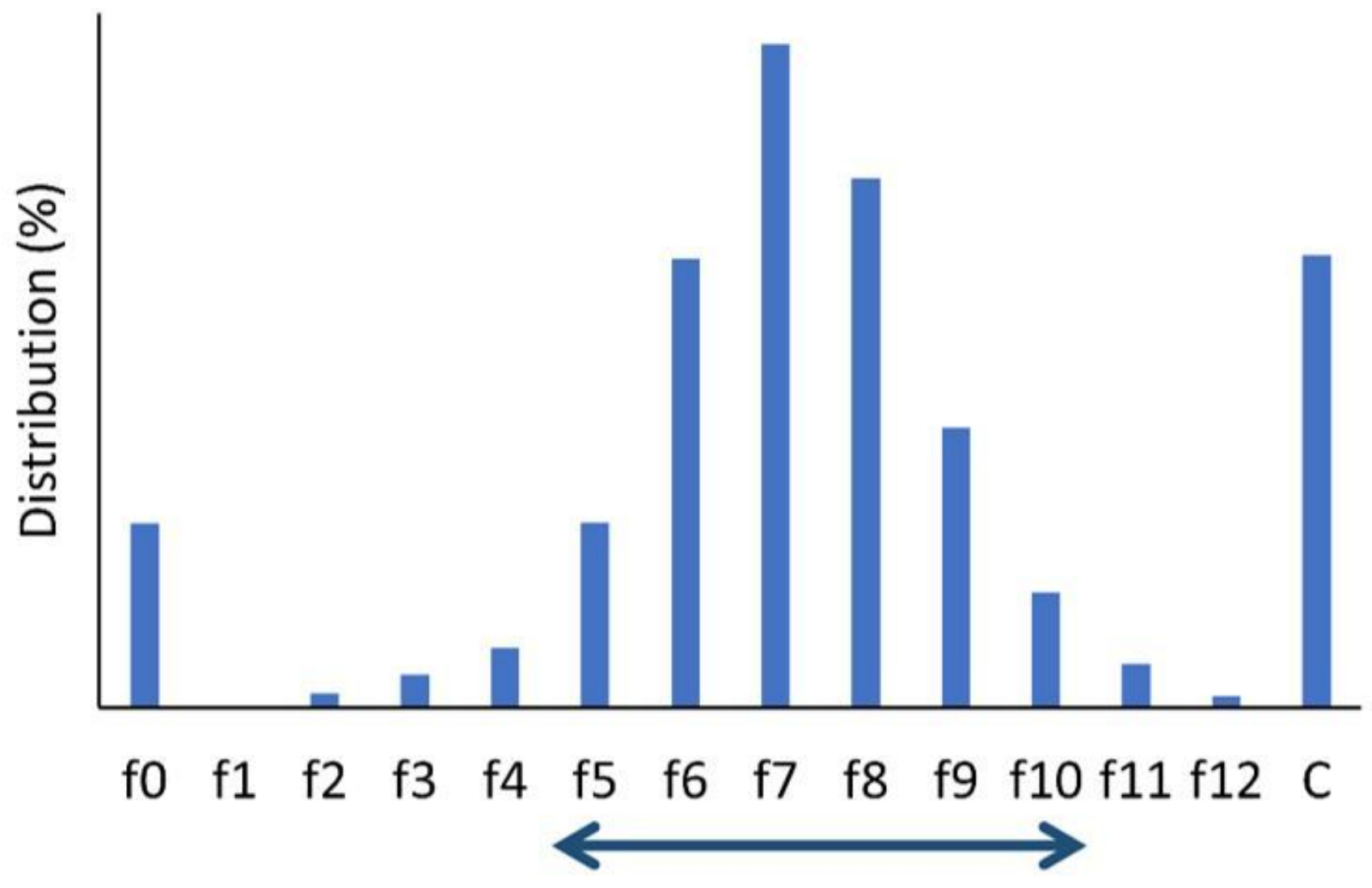

Figure 2

Radiochromatogram obtained during QMA-purification (f0: non-retaining fraction before elution, C: residual on the column) Fractions from $f 5$ to $f 10$ were collected.

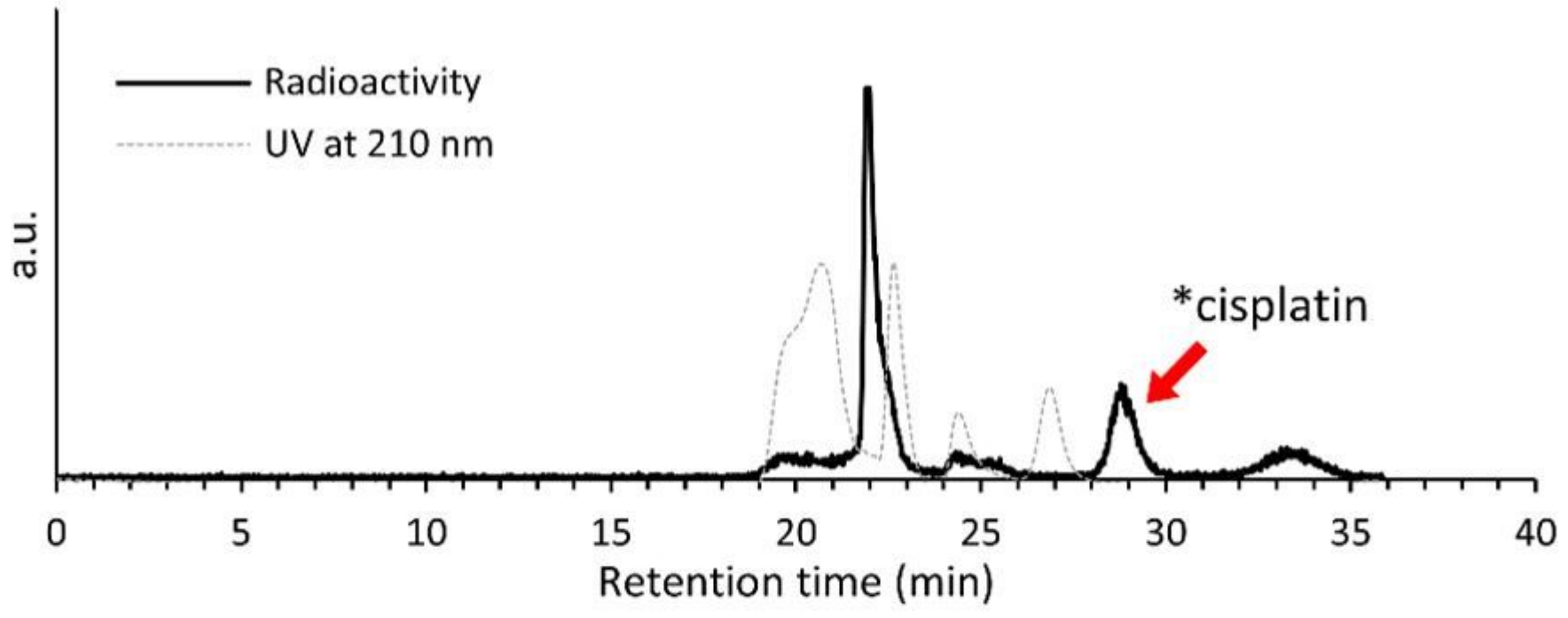


Figure 3

Radiochromatogram obtained during preparative HPLC

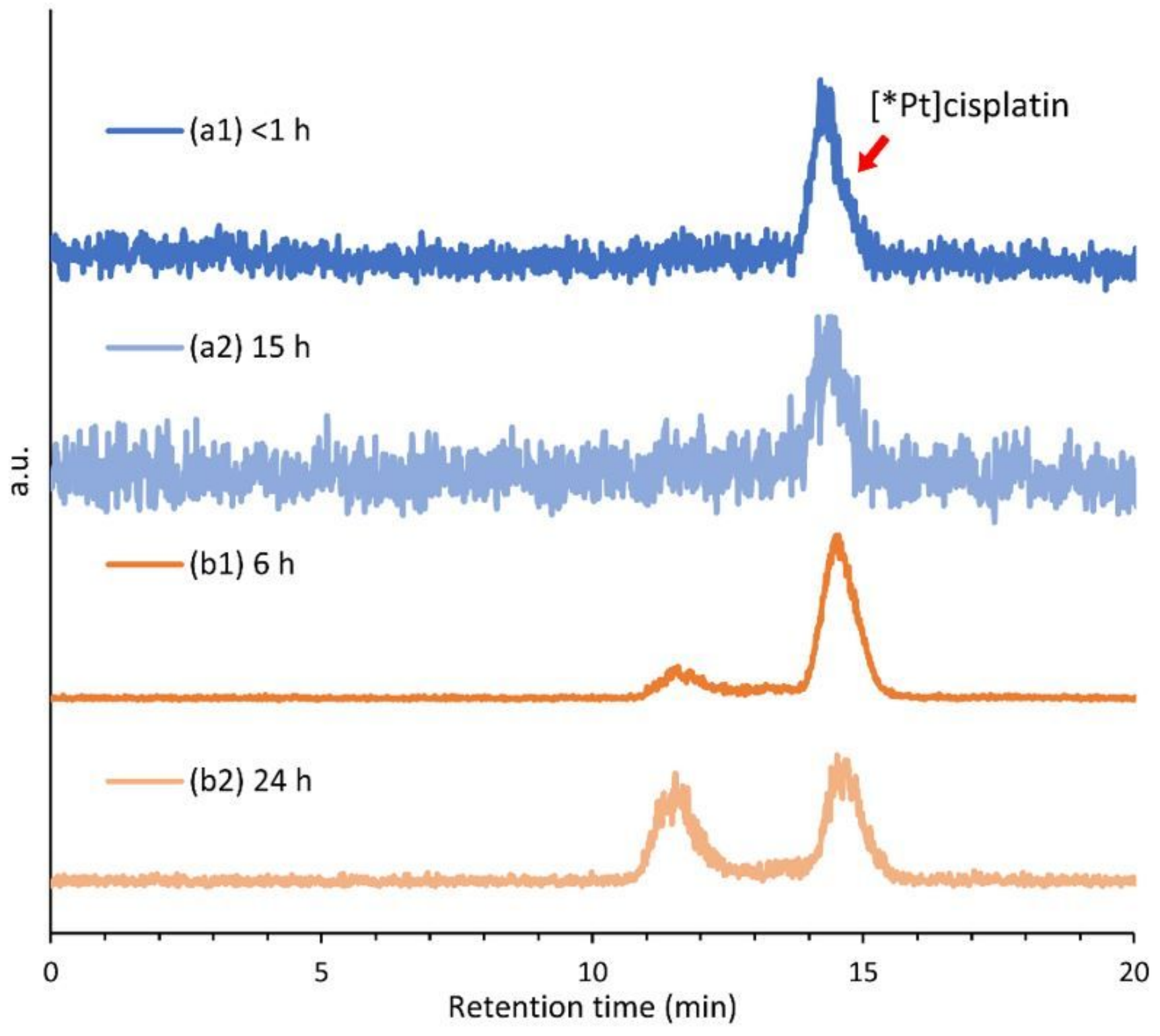

Figure 4

Radiochromatograms of a [*Pt]cisplatin product (a) $0.37(189 \mathrm{Pt})+0.31(191 \mathrm{Pt})+0.01(188 \mathrm{Pt}) \mathrm{MBq} / \mathrm{mL}$ at EOS, (b) $1.76(189 \mathrm{Pt})+1.40(191 \mathrm{Pt})+0.05(188 \mathrm{Pt}) \mathrm{MBq} / \mathrm{mL}$ at EOS 